\title{
ARKEOFAUNA KAWASAN KARST BONTOCANI KABUPATEN BONE, SULAWESI SELATAN
}

\author{
The Archaeofauna of Bontocani Karst Area, Bone, South Sulawesi
}

\author{
Fakhri \\ Balai Arkeologi Sulawesi Selatan \\ Jl. Pajjaiyang No. 13 Sudiang Raya Makassar, Indonesia \\ fakhri@kemdikbud.go.id
}

Naskah diterima: 18/03/2018; direvisi: 31/03-28/06/2018; disetujui: 20/07/2018

Publikasi ejurnal: 31/07/2018

\begin{abstract}
This study aims to provide a description of the fauna that once interacted with human in the Bontocani karst Area in Bone District. Of the few excavated sites providing data availability of bone fragments that can be analyzed by conducting comparative studies with existing faunal composition of the fauna. The method of data collection is by excavation at some sites in this Karst Area. The results of this study document a wide range of vertebrates in the Balang Metti fauna including fish, frogs/toads, lizards, snakes, birds, Strigocuscus, Ailurops ursinus, insectivorous bats, Sulawesi monkeys, rats, Sulawesi pigs, babirusa and Anoa. In some layers of culture, the absence of anoa, indicates the environmental change from the environment of the fields and the weeds to the wet rain forest environment around the site, along with the extinction of this fauna. Based on the identified fauna bone analysis, it is illustrated that past habitats and environments in Bontocani Karst area have not changed much.
\end{abstract}

Keyword: Vertebrate fauna, karst area, environment, habitation.

\begin{abstract}
Abstrak
Penelitian ini bertujuan memberikan gambaran secara lebih jelas tentang fauna-fauna yang pernah berinteraksi dengan manusia pendukung kebudayaan yang ada di Kawasan Karst Bontocani di Kabupaten Bone. Beberapa situs yang telah diekskavasi memberikan ketersediaan data berupa fragmen tulang yang dapat dianalisis dengan melakukan studi komparasi dengan komposisi tulang fauna yang ada saat ini. Metode pengumpulan data yang dilakukan adalah dengan ekskavasi di beberapa situs yang ada di Kawasan Karst ini. Hasil penelitian menunjukkan bahwa sebagian besar jenis fauna yang ditemukan di situs ini adalah fauna bertulang belakang antara lain: ikan, kodok/katak, kadal, ular, burung, strigocuscus, Ailurops ursinus, kelelawar pemakan serangga, monyet sulawesi, tikus, babi sulawesi, babi russa dan anoa. Pada beberapa lapisan budaya, tidak adanya temuan fauna anoa, menunjukkan perubahan lingkungan dari lingkungan padang dan ilalang menjadi lingkungan hutan hujan basah di sekitar situs, seiring dengan punahnya fauna ini. Berdasarkan analisis tulang fauna yang berhasil diidentifikasi digambarkan bahwa habitat dan lingkungan masa lampau di Kawasan Karst Bontocani tidak banyak mengalami perubahan.
\end{abstract}

Kata Kunci: Fauna bertulang belakang, kawasan karst, lingkungan, habitat.

\section{PENDAHULUAN}

Pada awal abad 19 sampai pertengahan abad 20, analisis terhadap temuan tulang fauna banyak dilakukan oleh arkeolog dengan dibantu dari disiplin ilmu lain seperti biologi, zoologi dan paleontologi, namun sampai sekarang para ahli arkeologi pun banyak yang mencoba membuat sistem analisis tersendiri meskipun tetap menggunakan kerangka dasar analisis disiplin ilmu lain- dengan melihat pengaruh lingkungan dan fisik hewan terhadap pola kebudayaan yang timbul. Penggabungan peranan disiplin ilmu lain dalam kajian arkeologi ini, tentunya sebagai metode untuk menjawab pertanyaan 
arkeologis yang sering berhubungan dengan pengaruh lingkungan dalam interaksi kebudayaan manusia. Selain itu, para ahli arkeologi pun berusaha membuat sebuah konsep analisis terhadap segala macam pengaruh fauna dalam kehidupan dan interaksi manusia. Model analisis inilah yang kemudian sering disebut sebagai kajian analisis arkeofauna (Davis, 1987; Landon, 2005). Kajian arkeofauna ini memiliki banyak penamaan dan peristilahan (Casteel \& Grayson, 1977; Lyman, 1994), meskipun demikian, kajian ini tetap perlu dilakukan dengan pertimbangan pentingnya data kehadiran fauna dalam satu ruang aktivitas jelajah manusia masa lampau.

Clason (1976) dalam uraian artikelnya menjelaskan tentang tinggalan fauna dari kawasan situs prasejarah LeangLeang, Maros, menyebutkan bahwa setidaknya ada lima alasan kajian artefak tulang fauna menjadi penting. Pertama, studi tentang tulang sebagai sisa peninggalan fauna akan memberikan informasi bagi kita tentang spesies yang pernah ada pada mereka dan saling berinteraksi dengan manusia di suatu wilayah dan selama periode tertentu. Hubungan interaksi tersebut dapat sebagai objek hewan buruan ataupun domestikasi (pengembangbiakan). Kedua, informasi tentang lingkungan, pemukiman dan vegetasi pada masa lampau dapat diperoleh dari kajian data kehadiran atau bahkan ketidakhadirannya spesies fauna pada habitat masing-masing untuk hidup berdampingan dengan manusia. Ketiga, kajian arkeofauna ini bisa memberitahukan kepada kita tentang pola makan dan sistem subsistensi manusia pendukung sebuah kebudayaan. Hal ini dapat memberi jawaban, bagaimana keterampilan mereka memanfaatkan sumber makanan di lingkungannya. Keempat, alasan penting lainnya ialah kajian arkeofauna dapat memberitahukan kepada kita tentang bagaimana proses budaya dalam kegiatan perburuan, memancing hingga teknik pengolahan fauna. Kelima, kajian ini dapat memberitahukan kepada kita kapan periode awal seekor spesies fauna mulai untuk dijinakkan dan didomestikasi serta bagaimana proses tersebut berlangsung (Clason, 1976). Namun sangat disayangkan, sampai saat ini penelitian tentang awal mula domestikasi fauna untuk wilayah bagian selatan Sulawesi belum memiliki data dan uraian memadai untuk membuktikan proses ini (Fakhri, 2017c).

Berbeda dengan Clason, Reitz dan Wing menyederhanakan tujuan penelitian arkeofauna menjadi dua bagian. Tujuan tersebut antara lain menyebutkan bahwa penelitian arkeofauna adalah untuk memahami ruang dan waktu termasuk lingkungan biologi dan ekologi fauna yang hidup di suatu masa dan tempat. Tujuan kedua yang disebutkan adalah untuk memahami struktur dan fungsi serta tingkah laku manusia dalam berinteraksi dengan fauna yang hidup di satu konteks yang sama. Untuk mencapai tujuan ini diperlukan kajian multidisiplin mulai dari ilmu biologi dan kimia, antropologi dan arkeologi itu sendiri (Reitz \& Wing, 2008).

Penelitian tentang jenis fauna endemik wilayah sulawesi sebenarnya telah dilakukan oleh beberapa peneliti pendahulu sejak tahun 1970an (Glover, 1973; Groves, 2001; Mulvaney \& Soejono, 1970). Penelitian ini setidaknya telah memberikan informasi mendasar tentang jenis fauna yang pernah ada dan berinteraksi dengan manusia pendukung kebudayaan di Sulawesi. Menyinggung tentang sejarah penelitian arkeofauna di Sulawesi, pada tahun 1980, sebelum bidang arkeometri didirikan, pekerjaan arkeologi mengenai paleozoologi (invertebrata dan vertebrata) terutama dari jenis vertebrata (hewan bertulang belakang) sudah dirintis dengan adanya kerjasama antara Puslit Arkenas dengan P3G dan Bioanthropologi UGM, kemudian secara bertahap juga mulai dilakukan oleh Rokhus Due Awe yaitu mengenai identifikasi dan klasifikasi fauna di Lembah Bada, Palu Sulawesi Tengah pada tahun 1977 dan 
beberapa penelitian lainnya di Indonesia (Vita, 2002). Untuk penelitian paleozoologi atau arkeofauna sebenarnya masih dapat dilakukan dengan sistem pembelajaran terpadu oleh peneliti yang memiliki kompetensi dalam identifikasi fauna, hal ini sangat dimudahkan, mengingat penelitian yang berkaitan dengan analisis arkeofauna tidak menggunakan peralatan yang rumit dan bahan kimia yang mudah diperoleh (Vita, 2002). Lebih lanjut, kehadiran fauna sebagai salah satu faktor pendukung kehidupan masyarakat gua pada masa lampau memberikan satu gambaran tersendiri tentang kondisi lingkungan dan cara hidup manusia. Sebagai contoh, kehadiran fauna dalam kehidupan prasejarah tidak terbatas hanya sebagai bahan konsumsi, namun ada juga yang bersentuhan dengan kondisi pemanfaatan praktis hingga sakralisasi. Dalam pembahasan artikel ini, penulis membatasi pembahasan fauna sebagai salah satu bagian ekosistem dalam lingkungan manusia. Data ini diharapkan dapat memberikan gambaran interpretasi tentang lingkungan pada masa lampau.

Kajian arkeofauna di Sulawesi masih perlu mendapat perhatian serius dari kalangan peneliti arkeologi. Perhatian terhadap fauna dalam konteks arkeologis yang pernah berinteraksi dengan manusia seringkali hanya terbatas pada interpretasi bentuk hubungan manusia dan hewan sebagai sumber bahan pangan. Hasil penelitian yang menunjukkan jenis-jenis fauna yang pernah hadir dalam ruang aktivitas manusia masih sangat kurang dan tidak up to date. Salah satu ruang aktivitas budaya manusia yang memberikan data fauna dari sebuah penggalian yang cukup baik adalah ditemukan di Situs Gua Balang Metti dan Situs Cappa Lombo, Kecamatan Bontocani, Kabupaten Bone.

Beranjak dari latar belakang tersebut di atas, permasalahan yang akan diajukan dalam penelitian ini adalah apa saja jenis fauna yang ditemukan dan menjadi bagian asosiasi temuan arkeologis dalam kotak ekskavasi yang telah dilakukan? Bagaimana bentuk pemanfaatan tulang sebagai artefak dalam aktivitas kehidupan manusia pendukung kebudayaan di Kawasan Karst Bontocani. Selain itu, penelitian ini juga berusaha menjawab bagaimana rekonstruksi lingkungan Kawasan Karst Bontocani pada masa penghuniannya?

\section{METODE PENELITIAN}

Analisis tulang fauna dan gigi dari penelitian ekskavasi Situs Gua Balang Metti dan Situs Cappa Lombo dilakukan di Laboratorium Analisis Temuan Arkeologi Balai Arkeologi Sulawesi Selatan dengan menggunakan koleksi tulang pembanding dari Balai Arkeologi Sulawesi Selatan berupa sampel tengkorak monyet (macaca), kuskus (ailurops ursinus), anjing muda (juvenile dog), tikus (muridae) burung (bird), kelelawar (megachiroptera) dan babi (sus scrofa). Selain itu, Bahan lain yang digunakan sebagai pembanding dalam analisis adalah koleksi foto DR. Phillip J. Piper berupa foto sampel tulang fauna dari Rijksmuseum van Natuurlijke HistorieLeiden, Belanda.

Proses analisis dan pengidentifikasian menggunakan metode penghitungan jumlah fragmen tulang yang dapat diidentifikasi, sehingga menghasilkan nominal NISP (Number of Identified Speciment). Angka ini merupakan representasi dari jumlah tulang yang dapat diidentifikasi hingga class takson dapat diketahui. Selain itu, data ini dapat memberikan informasi mengenai habitat dan lingkungan secara umum dari situs yang dilakukan penggalian. Selain NISP, penghitungan lain yang dilakukan dalam analisis tulang adalah dengan menghitung jumlah individu minimal dari satu jenis hewan. Penghitungan ini sering juga disebut MNI (Minimum Number of Individu). Penghitungan ini dilakukan dengan mengamati bagian tulang yang memiliki artikulasi untuk diidentifikasi, terutama 
identifikasi terhadap orientasi bagian kanan dan kiri temuan tulang pada bagian anatomi tubuh hewan.

Pada analisis tulang fauna dilakukan pembagian terhadap jenis tulang yang ditemukan. Pembagian tersebut secara umum terbagi menjadi 2, yaitu tulang yang dapat diidentifikasi (identiifed) dan tulang yang tidak dapat diidentifikasi (unidentified). Fragmen tulang yang dapat diidentifikasi akan diklasifikasi berdasarkan taksonominya mulai dari Class, Ordo, Family dan Takson nya, demikian juga diberikan batasan dalam bahasa Inggris dan bahasa umumnya. Pada bagian tulang yang tidak dapat diidentifikasi, diklasifikasi menjadi 3 bagian yaitu, tulang mamalia (mammals), tulang yang dapat diidentifkasi (unidentified bones) dan takson yang tidak dapat diidentifikasi (unidentified taxon). Pembagian fragmen tulang yang tidak dapat diidentifikasi menjadi mamalia adalah identifikasi yang dilakukan terhadap tulang dan hanya dapat diidentifikasi sebagai tulang fauna mamalia. Untuk fragmen tulang yang tidak dapat diidentifkasi adalah fragmen tulang yang tidak memiliki atribut dan artikulasi yang kuat untuk diidentifikasi, sehingga untuk fragmen ini hanya dapat disebut sebagai tulang yang tidak dapat diidentifikasi. Adapun takson yang tidak dapat diidentifikasi adalah pemgagian tulang yang dapat diidentifkasi sebagai mamalia atau fauna namun tidak dapat dipastikan jenis faunanya. Hal ini dilakukan untuk mengurangi tingkat kesalahan dalam melakukan analisis dan identifikasi terhadap fragmen tulang yang ditemukan.

\section{HASIL DAN PEMBAHASAN}

\section{Temuan Arkeologis dalam Kotak Ekskavasi}

\section{a. Kotak Gali U3 T2}

Analisis temuan tulang dari Situs Balang Metti kotak U3 T2 menghasilkan jumlah tulang sebanyak 3.191 fragmen dengan berat total 1109,79 gr. Adapun jumlah tulang yang dapat diidentifikasi sampai pada class atau tingkat takson yang lebih tinggi adalah sebanyak 323 fragmen atau sebanyak $10.1 \%$ (lihat gambar 3). Tulang yang tidak dapat diidentifikasi sampai pada tingkat class namun masih dapat diketahui sebagai mammal, unidentified taxon, dan unidentified bones adalah sebanyak 2.868 fragmen atau $89.9 \%$ (lihat gambar 1). Adapun penyebab temuan tulang tidak dapat diidentifikasi adalah karena kondisinya yang sangat fragmentaris. Kondisi tulang yang sangat fragmentaris tersebut hanya dapat memberikan data berupa kondisi tulang secara umum, salah satunya adalah kondisi tulang yang terbakar dan tidak terbakar. Beranjak dari data total keseluruhan jumlah tulang yang ditemukan pada kotak gali ini, jenis fauna yang ditemukan cukup berimbang dari bila dilihat

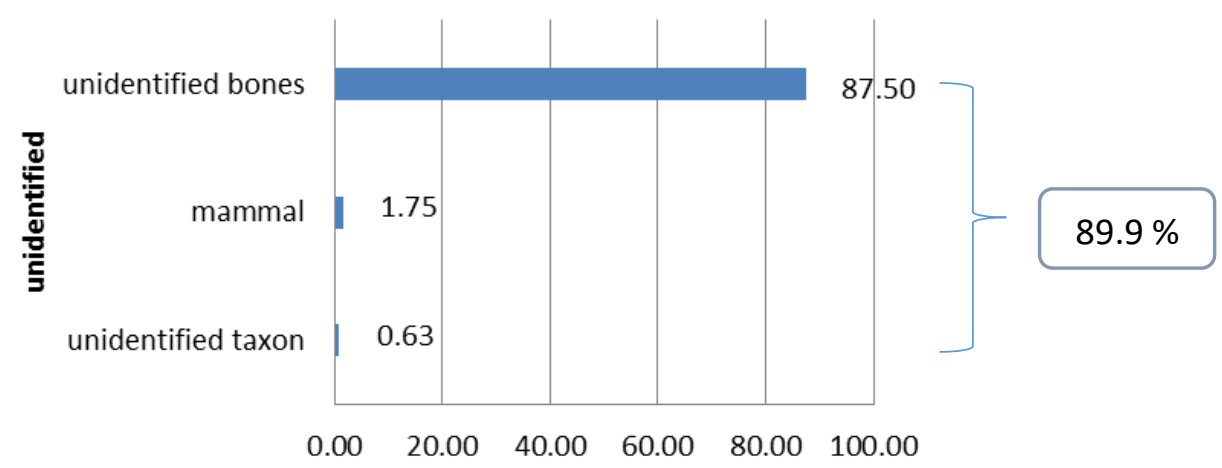

Gambar 1. Persentase tulang yang tidak dapat diidentifikasi pada kotak U3T2 Situs Balang Metti (sumber: Dokumentasi Balar Sulsel, 2016) 


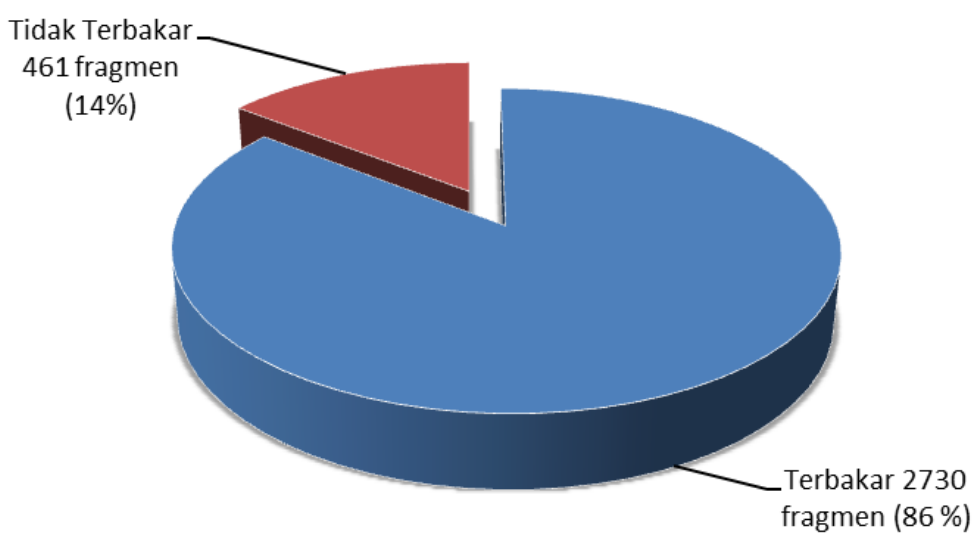

Gambar 2. Diagram persentase tulang terbakar dan tidak terbakar (Sumber: Dokumentasi Balar Sulsel, 2016)

dari habitatnya, baik hewan dengan habitat ekosistem air, hutan dan atau pun lingkungan padang terbuka.

Banyaknya temuan fragmen tulang yang tidak dapat diidentifikasi menunjukkan bahwa dalam satu lapisan budaya pemanfaatan terhadap fauna yang ada di sekitar lingkungan situs dapat dimaksimalkan oleh manusia pendukung kebudayaannya. Sampah tulang dari sisa aktivitas diet dan proses pembuatan artefak tulang memungkinkan banyaknya fragmen tulang yang tidak dapat diidentifikasi. Proses pengerjaan dan proses memecahkan tulang untuk mendapatkan dan memenuhi sumber gizi dan energi.

Secara umum, kondisi tulang yang dianalisis menunjukkan kondisi yang sangat rapuh dan mudah patah. Hal ini disebabkan oleh tanah pengendap tempat temuan tulang ditemukan. Sebagian besar tulang yang ditemukan dengan indikasi pembakaran berwarna hitam dan sebagian besar berwarna agak coklat gelap. Penggunaan api dalam aktivitas masa lampau nampaknya sudah menjadi tren yang sangat dikenal oleh masyarakat manusia pendukung kebudayaan gua Balang Metti. Pemanfaatan api sebagai salah satu kebutuhan hidup nampaknya dapat dimaksimalkan oleh manusia pendukung Gua Balang Metti. Dari identifikasi terhadap temuan tulang terbakar dan tidak terbakar menunjukkan bahwa sebanyak $86 \%$ temuan tulang di kotak gali ini dalam kondisi terbakar (lihat gambar 2). Temuan tulang terbakar ini menunjukkan bahwa pemanfaatan api merupakan salah satu hal yang paling berpengaruh dalam aktivitas budaya mereka.

Dari hasil identifikasi terhadap temuan tulang, terutama yang terkait dengan identifikasi terhadap taksonomi, ditemukan hanya 323 fragmen tulang yang dapat diidentifikasi untuk disebutkan jenis taksonominya. Adapun jenis hewan tersebut antara lain: Ikan, katak, kadal, ular, burung, kuskus sulawesi besar dan kuskus sulawesi kecil, kelelawar pemakan serangga, monyet, tikus, babi dan anoa. Temuan jenis hewan berupa babi sangat besar kemungkinan adalah dari jenis babirusa dan atau sus celebensis sebagai salah satu hewan endemik yang ada di pulau Sulawesi sebelum masa kepunahannya. Untuk jumlah fragmen tulang yang dapat diidentifikasi dan jumlah hewan yang dapat dihitung jumlah individu minimalnya dapat dilihat pada gambar 3 dan lampiran tabel 1.

Data tentang hewan yang cukup menarik dapat kita amati pada jumlah kehadiran tikus dan babi. Hewan tikus atau jenis hewan pengerat lainnya diamati menunjukkan kehadiran yang cukup berimbang pada setiap spit kotak gali. Hal 




Gambar 3. Persentase jenis fauna dalam kotak U3T2 Situs Balang Metti

(Sumber: Dokumentasi Balar Sulsel, 2016)

ini berlaku umum, kecuali pada permukaan spit 1. Kondisi tulang tikus pada spit permukaan sampai pada spit 3 sebagian besar merupakan fragmen tulang tikus yang berasal dari permukaan. Kondisi dan warna tulang memberikan informasi bahwa tulang tikus berasal dari pengendapan yang masih baru (fauna recent). Sebaran tulang pada spit-spit awal (1 sampai 3) kemungkinan adalah sisa makanan binatang gua lainnya, seperti burung elang dan atau binatang lainnya. Meskipun demikian, tidak dapat diabaikan data kondisi tulang tikus yang terbakar pada spit yang jauh lebih dalam lagi (5 sampai 7) menunjukkan sisa aktivitas diet atau aktivitas pemenuhan kebutuhan hidup berupa makan.

Temuan fragmen tulang yang diidentifikasi sebagai tulang suidae (babi) merupakan jenis tulang hewan yang memiliki jumlah yang cukup banyak setelah temuan fragmen tulang tikus - pada kotak gali U3 T2. Kondisi ini menunjukkan tingkat pengkonsumsian hewan babi merupakan aktivitas diet yang cukup tinggi. Usaha perburuan dan pengkonsumsian hewan ini dapat dilihat pada padatnya temuan fragmen tulang pada spit 5 dan spit
2. Kondisi tulang sebagian besar terbakar dengan menyisakan residu pembakaran (arang).

\section{b. Kotak Gali U2 T2}

Analisis temuan tulang dari Situs Balang Metti kotak U2 T2 menghasilkan jumlah tulang sebanyak 2.805 fragmen dengan berat total 726.01 gr. Adapun jumlah tulang yang dapat diidentifikasi sampai pada class atau tingkat takson yang lebih tinggi adalah sebanyak 804 fragmen atau sebanyak $28,7 \%$ (lihat gambar 6). Tulang yang tidak dapat diidentifikasi sampai pada tingkat class namun masih dapat diketahui sebagai mammal, unidentified taxon, dan unidentified bones adalah sebanyak 2.001 fragmen atau 71,3\% (lihat gambar 4). Hal menarik dari pengamatan terhadap persentase tulang pada kotak gali U2T2 adalah jumlah temuan tulang terbakar yang tidak berbanding dengan temuan tulang dari kotak gali U3T2. Meskipun keletakan layout penggalian kedua kotak ini berdampingan, namun temuan tulang nampaknya memiliki persentase yang berbeda. Bila pada kotak U3T2 jumlah tulang terbakar mencapai $86 \%$, pada kotak U2T2 nampaknya memiliki 


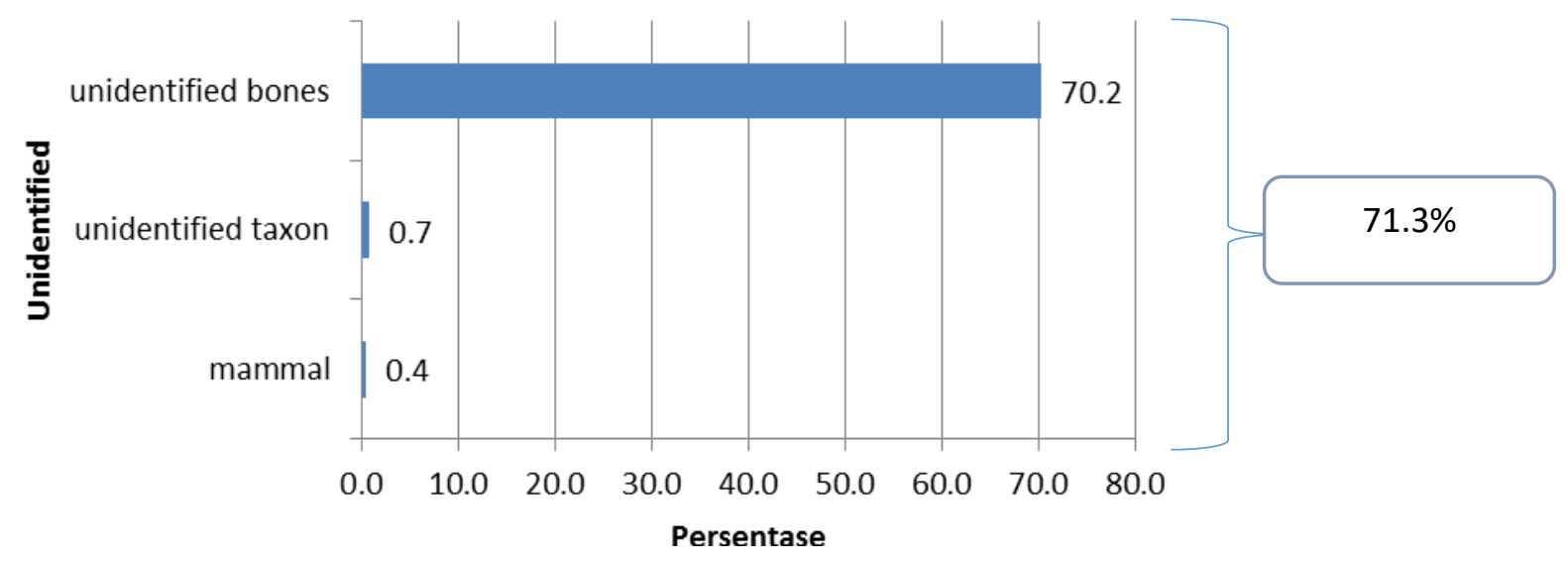

Gambar 4. Persentase tulang yang tidak dapat diidentifikasi pada kotak U2T2 Situs Balang Metti

(Sumber: Dokumentasi Balar Sulsel, 2016)

pengurangan jumlah yang sangat signifikan, yaitu hanya mencapai jumlah $30 \%$ dari total jumlah temuan fragmen tulang yang jumlahnya tidak jauh berbeda.

Penjelasan mengenai kehadiran tulang terbakar dan tidak terbakar pada kotak gali U2T2 nampaknya tidak jauh berbeda dengan kehadiran tulang di kotak U3T2. Hanya saja menjadi catatan penting untuk fragmen tulang tidak terbakar pada kotak U2T2 ini adalah berasal dari temuan fragmen tulang dari jenis fauna muridae (tikus dan atau hewan pengerat lainnya). Dari jumlahnya yang sangat banyak pada kotak gali ini, temuan tulang tikus tersebut banyak berasal dari lapisan tanah bagian permukaan, yaitu pada spit 2 dan spit 1 . Hal ini mengindikasikan bahwa temuan tulang tikus tersebut adalah berasal dari lapisan yang masih muda dan tidak menjadi satu konteks lapisan budaya dengan fragmen tulang yang terbakar.

Dari hasil identifikasi terhadap temuan tulang, terutama yang terkait dengan identifikasi terhadap taksonomi, ditemukan 804 fragmen tulang yang dapat diidentifikasi untuk disebutkan jenis taksonominya. Adapun jenis hewan tersebut antara lain: katak, kadal, ular, burung, kuskus sulawesi besar dan kuskus sulawesi kecil, kelelawar pemakan serangga, monyet sulawesi, tikus, babi dan anoa (lihat gambar 6 dan tabel 2). Untuk jumlah fragmen tulang yang dapat diidentifikasi dan jumlah hewan yang dapat dihitung jumlah individu minimalnya dapat dilihat pada diagram dan tabel di bawah.

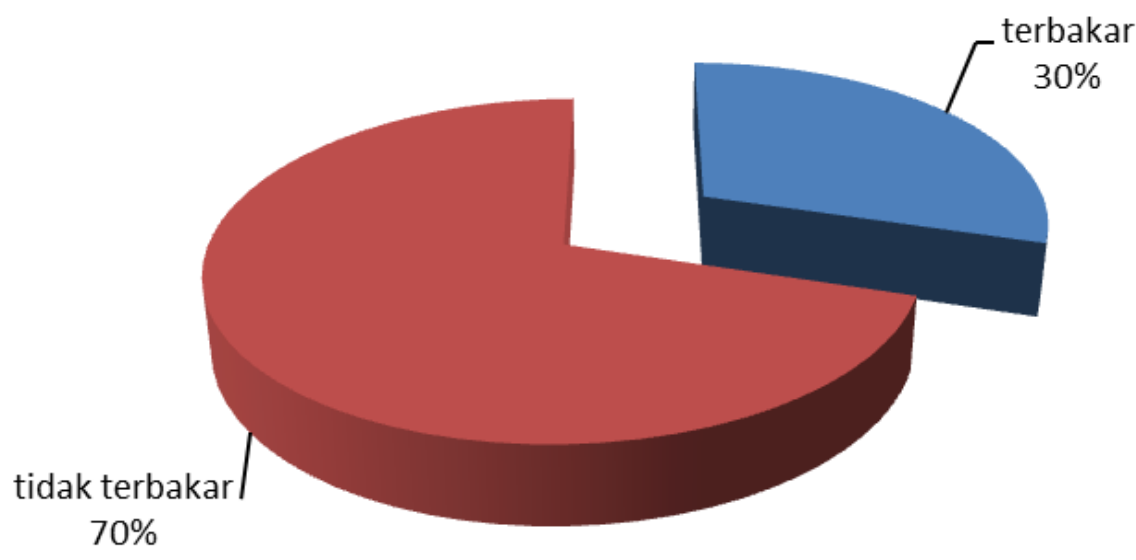

Gambar 5. Diagram persentase tulang terbakar dan tidak terbakar (Sumber: Dokumentasi Balar Sulsel, 2016) 




Gambar 6. Persentase jenis fauna dalam kotak U2T2 Situs Balang Metti

(Sumber: Dokumentasi Balar Sulsel, 2016)

Identifikasi terhadap jenis fauna yang ditemukan pada kotak gali U2T2 memperlihatkan jenis fauna mamalia yang juga lebih didominasi oleh hewan babi. Nampaknya babi memiliki peran penting dalam proses interaksinya dengan manusia pendukung Gua Balang Metti. Fauna ini dapat dianggap sebagai salah satu sumber makanan yang cukup banyak pada masa tersebut. Berbeda indikasi yang ditemukan berupa kurangnya ditemukan fragmen tulang yang dapat diidentifikasi sebagai hewan anoa (buballus depresicornis). Meskipun anoa tercatat sebagai salah satu hewan endemik pulau sulawesi, namun dengan kurangnya temuan fragmen tulang di situs Gua balang Metti, menunjukkan bahwa lingkungan padang terbuka dengan vegetasi rumput sangat kurang atau mungkin jauh dari lingkungan Gua Balang Metti pada masa lampau.

Dari analisis pula, ditemukan fauna yang banyak dimanfaatkan sebagai bahan makanan adalah monyet dan katak. Dengan persentase yang mencapai jumlah 1 sampai
$1,2 \%$, tampaknya monyet dan katak pun memiliki peran penting dalam proses pemenuhan bahan makanan.

\section{c. Kotak Gali U1 B2}

Penggalian kotak gali U1 B2 merupakan pencarian data yang dilakukan untuk mencari orientasi rangka individu 1 BM dan data vertikal yang dapat menjelaskan tentang eksistensi gua balang Metti pada masa penghuniannya. Data fauna yang berhasil diidentifikasi pada kotak gali ini sebagian besar memperlihatkan data fragmen yang tidak dapat diidentifikasi.

Analisis temuan tulang dari Situs Balang Metti kotak U1 B2 menghasilkan jumlah tulang sebanyak 1.696 fragmen dengan berat total 628,02 gr. Adapun jumlah tulang yang dapat diidentifikasi sampai pada Class atau tingkat takson yang lebih tinggi adalah sebanyak 203 fragmen atau sebanyak $12 \%$ (lihat gambar 9). Tulang yang tidak dapat diidentifikasi sampai pada tingkat class namun masih dapat diketahui sebagai mammal, unidentified taxon, dan 




Gambar 7. Persentase tulang yang tidak dapat diidentifikasi pada kotak U1B2 Situs Balang Metti (Sumber: Dokumentasi Balar Sulsel, 2016)

unidentified bones adalah sebanyak 1493 fragmen atau $88 \%$ (lihat gambar 7).

Jumlah fragmen tulang terbakar dan tidak terbakar memperlihatkan dominasi fragmen terbakar sampai $71 \%$ dan sisanya $29 \%$ adalah fragmen tulang tidak terbakar. Diagram di bawah ini menegaskan penjelasan pada kotak gali U3T2 bahwa penggunaan api pada masa penghunian Gua Balang Matti telah digunakan dengan sangat maksimal. Banyaknya fragmen temuan tulang terbakar juga menjelaskan tentang perlakukan manusia pendukung kebudayaan Gua Balang Metti. Perilaku budaya yang jelas dapat terlihat pada situs ini adalah pemanfaatan tulang untuk dijadikan sebagai artefak. Pemanfaatan tulang sebagai artefak dapat dilihat dari banyaknya, bahkan hampir semua artefak tulang yang ditemukan merupakan fragmen tulang yang terbakar.
Menyinggung tentang pemanfaatan api dalam hal pembakaran bahan makanan, beberapa jenis fauna yang ditemukan pun mengalami banyak sisa pembakaran. Hal ini dapat terlihat dari diagram di atas yang menunjukkan banyaknya persentase tulang yang terbakar. Adapun jenis fauna yang berhasil diidentifikasi pada kotak gali U1B2 antara lain adalah: katak, ular, kuskus sulawesi besar dan kuskus sulawesi kecil, kelelawar pemakan serangga, monyet, tikus, babi dan anoa (lihat tabel 3). Identifikasi jenis hewan tersebut dilakukan dengan melakukan identifikasi fragmen tulang yang masih memiliki artikulasi bentuk yang mudah dikenali sebagai salah satu jenis fauna yang pernah hidup di lingkungan Situs Balang Metti. Tingginya tingkat persentase kehadiran satu jenis fauna belum menjamin tingkat kebutuhan manusia pendukung

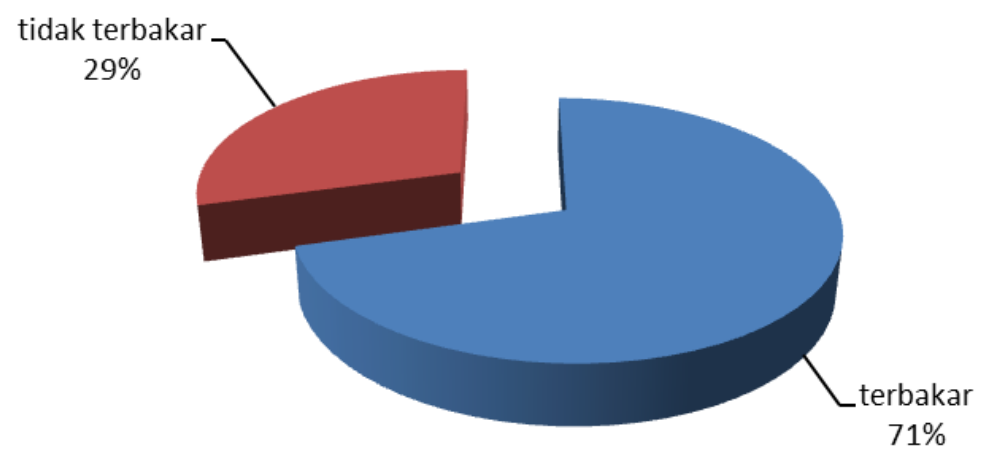

Gambar 8. Diagram persentase tulang terbakar dan tidak terbakar kotak U1B2 (Sumber: Dokumentasi Balar Sulsel, 2016) 


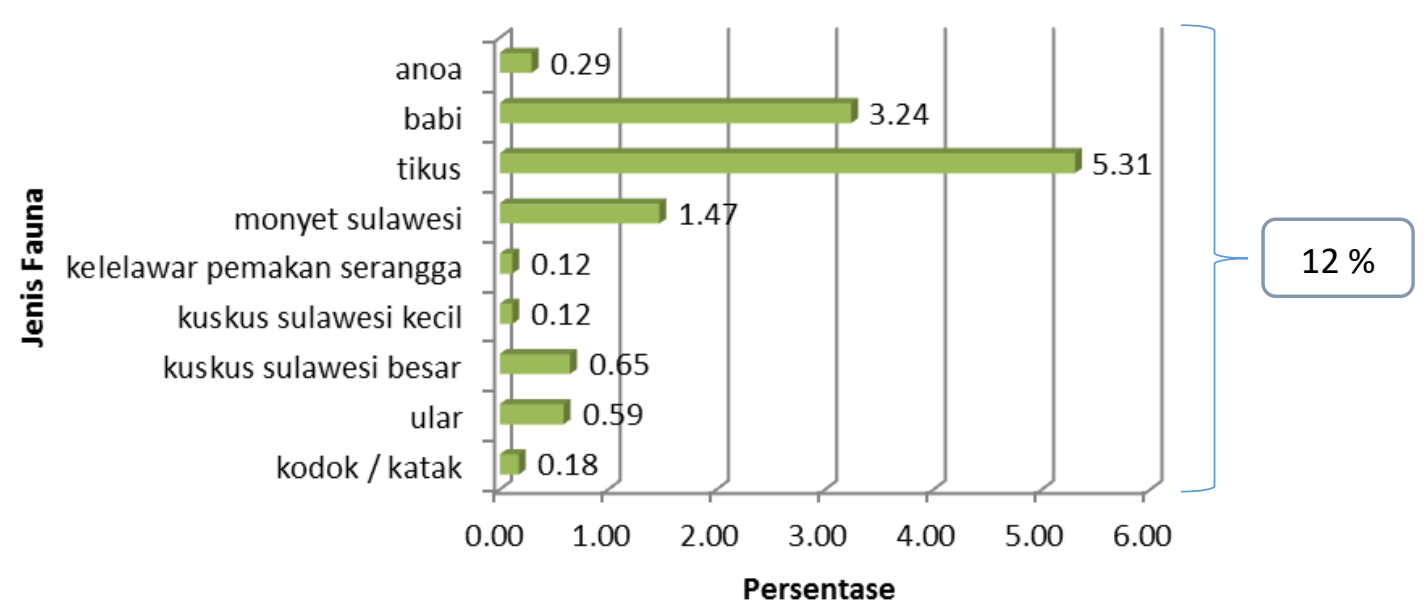

Gambar 9. Persentase jenis fauna dalam kotak U1B2 Situs Balang Metti

(Sumber: Dokumentasi Balar Sulsel, 2016)

terhadap fauna tersebut. Namun indikasi ini dapat menjelaskan tentang banyaknya atau padatnya populasi suatu jenis hewan tertentu dalam satu lingkungan situs. Seperti pada diagram persentase jenis hewan yang ada di bawah ini, menunjukkan bahwa jenis hewan pengerat seperti tikus memiliki persentase yang sangat tinggi.

\section{Pemanfaatan Tulang sebagai Artefak di Kawasan Karst Bontocani}

Salah satu bentuk pemanfaatan sisa fauna yang dimaksimalkan oleh manusia pendukung kebudayaan di Situs Cappa Lombo adalah pembuatan artefak dengan menggunakan bahan tulang dan atau gigi fauna. Artefak dari bahan fauna yang ditemukan di Situs Cappa Lombo ini adalah dari akar gigi bagian incissor babi. Analisis terhadap temuan artefak dari tulang dan atau



Gambar 10. Artefak tulang yang ditemukan di Situs Cappa Lombo ditemukan dalam kondisi patah (Sumber: Dokumentasi Balar Sulsel, 2017) 




Gambar 11. Temuan artefak tulang yang terbuat dari bahan akar gigi babi yang ditemukan pada ekskavasi di Kawasan Karst Bontocani

(Sumber: Dokumentasi Balar Sulsel, 2017)

gigi fauna ini teridentifikasi dari bekas pemotongan dan bekas penggunaan yang berpola pada permukaan tulang (lihat gambar 10). Pola striasi dengan bentuk melintang pada permukaan tulang menjadi salah satu jejak bekas pemakaian secara intensif oleh manusia pendukung kebudayaan di Situs Cappa Lombo.

\section{Rekonstruksi Lingkungan Kawasan Karst Bontocani Pada Masa Penghuniannya}

Dari data temuan fragmen tulang dan gigi pada beberapa situs di Kawasan Karst Bontocani, menunjukkan beberapa jenis fauna yang pernah hidup dan berinteraksi dengan manusia pendukung kebudayaan gua. Hewan-hewan ini merupakan bahan referensi ekofak yang dapat menceritakan tentang lingkungan masa lampau di satu ruang wilayah budaya. Hasil identifikasi terhadap taksonomi dan latar belakang lingkungan tempat tinggal hewan tersebut dapat diketahui bahwa pada lingkungan tersebutlah manusia pendukung kebudayaan Gua Balang Metti hidup dan berinteraksi dengan lingkungannya. Adapun hewan berupa ikan, ular, katak dan beberapa jenis hewan pengerat menunjukkan lingkungan rawa dangkal yang juga sebagai habitat hewan lainnya. Beberapa jenis hewan yang memiliki habitat lingkungan berupa hutan hujan basah dan lingkungan gua dengan intensitas kelembaban yang rendah adalah babi, kuskus, monyet dan beberapa lingkungan berupa tanah lapang dan padang merupakan habitat hewan berupa anoa dan beberapa jenis mamalia lainnya.

Analisa terhadap jenis temuan fauna yang ada di lingkungan Gua Balang Metti pada masa lampau mengantarkan peneliti pada kesimpulan bahwa kondisi tersebut kemungkinan tidak jauh berbeda dengan lingkungan saat ini. Hal ini didasarkan pada masih banyaknya habitat yang tersedia di sekitar situs untuk memungkinkan jenis fauna tersebut untuk terus bertahan hidup. Lebih lanjut lagi, bila dilihat dari jenis temuannya, pendukung kebudayaan Gua Balang Metti belum mengenal sistem domestikasi, sehingga kebutuhan makan sangat bergantung pada ketersediaan alam. Proses berburu dan mengumpulkan makanan masih menjadi tren masa itu untuk 
pemenuhan diet dan aktivitas kehidupan masyarakat.

Dari hasil analisis tersebut di atas, dapat disimpulkan berupa aktivitas budaya yang terjadi terkait dengan lingkungan masa lampau di Situs Gua Balang Metti. Lingkungan purba Situs Balang Metti adalah sebuah tempat manusia beraktivitas dalam hubungannya dengan proses pemenuhan makanan. Proses perolehan makan di lingkungan rawa, hutan hujan basah dan padang rumput merupakan sebuah aktivitas yang membutuhkan tenaga ekstra untuk bertahan hidup. Pemanfaatan ruang gua di Balang Metti ini merupakan pemilihan lokasi yang tepat, mengingat kondisi gua yang cukup teduh dan dapat terhindar dari paparan sinar matahari langsung dan sebagai shelter atau tempat berteduh di saat hujan. Sehingga tidak menjadi sesuatu yang mengherankan bila gua ini dimanfaatkan sebagai lokasi bermukim dan lokasi aktivitas pemenuhan diet berupa tempat mengumpulkan dan mengolah makanan dari fauna. Terkait dengan keberadaan rangka manusia, sampai saat penelitian ini dilakukan, tidak ditemukan adanya bekas penggalian atau fitur dalam tanah yang menunjukkan bahwa rangka manusia ini sengaja ditanam. Namun sebaliknya, dari proses penggalian ditemukan adanya indikasi bahwa rangka ini diletakkan bersama dengan susunan struktur batuan yang mengelilingi rangka individu $1 \mathrm{BM}$ (Fakhri, 2017b; Hakim, 2017).

Identifikasi fauna berhubungan dengan kehadiran rangka manusia pada kotak gali U1 B2 memberikan data perubahan fauna yang pernah eksis di lingkungan ini. Temuan rangka manusia pada kedalaman $70 \mathrm{~cm}$ sebagai bukti eksistensi kehadiran manusia di kawasan ini diidentifikasi sebagai bangsa Austronesia dengan ciri mongoloid (Fakhri, 2017b). Adapun fauna yang ditemukan pada masa sebelum kehadiran manusia pada lapisan dibawah rangka manusia ini antaralain: sebagian besar didominasi oleh fauna suidae (babi sulawesi), buballus depresicornis (anoa) dan macaca maura(monyet sulawesi). Sedangkan pada lapisan di atas rangka manusia lebih banyak didominasi oleh fauna kecil antara lain katak, ailurops ursinus, kelelawar, tikus, ular dan masih ditemukan pula berupa babi sulawesi dan anoa dalam jumlah yang tidak terlalu banyak.

Secara umum, kondisi temuan fragmen tulang fauna yang ditemukan telah mengalami proses penghancuran secara alami, meskipun pada beberapa bagian masih dapat diamati secara jelas. Kondisi tulang agak rapuh dan belum terlihat adanya proses fosilisasi, dan kondisi tulang masih tersusun atas unsur organik asli material tulang. Hal ini menunjukkan proses fosilisasi yang belum terjadi yang sangat besar dimungkinkan oleh 2 (dua) sebab, yang pertama adalah lokasi pengendapan dan yang kedua adalah masa atau waktu pengendapan (Fakhri, 2017a). Lokasi pengendapan unsur organik yang mendukung proses fosilisasi adalah lingkungan endapan vulkanik atau lingkungan kapur. Sementara itu, waktu yang dibutuhkan untuk proses fosilisasi adalah minimal berusia 7000 tahun (Widianto, 2006). Hasil penelitian ini nampaknya juga masih sejalan dengan hasil penelitian yang dilakukan oleh Soejono yang menyebutkan bahwa alam fauna yang ditemukan dari hasil penelitian purbakala di beberapa gua di nusantara, termasuk di Sulawesi, menunjukkan persamaan dengan hewan-hewan sekarang, meskipun beberapa spesies tertentu menunjukkan bentuk-bentuk lebih besar daripada hewan sekarang (Poesponegoro, Notosusanto, Soejono, \& Leirissa, 2009).

\section{PENUTUP}

Kebudayaan yang dihasilkan oleh manusia di Kawasan Karst Bontocani bukan hanya terbatas pada aktivitas pembuatan artefak batu dengan pola teknologi yang mereka kuasai. Dalam penelitian ini, 
ditemukan bahwa sisa fauna pun menjadi salah satu bahan pertimbangan dalam menghasilkan kebudayaan. Artefak dengan menggunakan sisa fauna menjadi tren tersendiri pada masa penghunian Kawasan Karst Bontocani. Dari uraian tersebut di atas, disimpulkan bahwa dari ketersediaan data arkeofauna Kawasan Karst Bontocani menggambarkan lingkungan dan habitat fauna tidak terlalu banyak berubah dan sebagian besar masih dalam bentuknya yang alami.

Hasil penelitian menunjukkan bahwa sebagian besar jenis fauna yang ditemukan di situs ini adalah fauna bertulang belakang antara lain: ikan, kodok/katak, kadal, ular, burung, strigocuscus, Ailurops ursinus, kelelawar pemakan serangga, monyet sulawesi, tikus, babi sulawesi, babi russa dan anoa. Adapun bentuk pemanfaatan sisa fauna berupa tulang dimanfaatkan sebagai alat pelubang dan atau alat penusuk dengan ciri penggunaan yang masih dapat diamati.
Pada beberapa lapisan, terkhusus pada lapisan yang mengandung sisa fauna anoa memberikan perubahan habitat pada lapisan sebelumnya. Lingkungan habitasi anoa berupa padang dan ilalang, menghilang pada kawasan karst Bontocani seiring dengan semakin punahnya fauna ini dan mempengaruhi perubahan lingkungan di sekitar situs bahkan sampai saat ini.

\section{Ucapan Terima kasih}

Terima kasih dan penghargaan yang sebesarbesar nya penulis sampaikan kepada Bapak Budianto Hakim sebagai senior dan menjadi pembimbing penulis dalam pengambilan dan pengolahan data lapangan. Penulis juga ucapkan penghargaan dan terimakasih yang sebesar-besarnya kepada Ibu Bernadeta AKW sebagai senior di Balai Arkeologi yang senantiasa memberikan semangat dan bimbingan dalam penulisan artikel ini.

\section{DAFTAR PUSTAKA}

Casteel, R. W., \& Grayson, D. . (1977). Terminology Problems in Quantitative Faunal Analysis. In World Archaeology (pp. 235-242).

Clason, A. T. (1976). A Preliminary Note About The Animal Remains From The Leang I Cave, South Sulawesi, Indonesia. Mod. Quaternary Res. SE Asia, 53-67.

Davis, S. J. (1987). The Archaeology of Animal. London: Routledge.

Fakhri. (2017a). Fauna dan Strategi Subsistensi Penghuni Situs Pangnganikang 4000 Tahun Yang Lalu. In M. I. Mahmud \& B. Hakim (Eds.), Butta Toa: Jejak arkeologi budaya Toala, logam dan tradisi berlanjut di Bantaeng (pp. 49-74). Makassar: Balai Arkeologi Sulawesi Selatan.

Fakhri. (2017b). Indentifikasi rangka manusia Situs Gua Balang Metti, Kabupaten Bone, Sulawesi Selatan. Walennae, 15(2), 89-100.

Fakhri. (2017c). Laporan Penelitian Arkeologi: Penelitian Prasejarah Kawasan Situs Bontocani. Makassar.

Glover, I. C. (1973). Preliminary Report on The Excavation of Ulu Leang Cave, Maros.

Groves, C. (2001). Mammals in Sulawesi: Where Did They Come From dan When, and What Happened to Them When They Got There. In I. Metcafe, M. J. Smith, M. J. 
Morwood, \& I. Davidson (Eds.), Faunal and Floral Migrations and Evolution in SE Asia (pp. 333-342). Tokyo: A. A. balkema Publisher/ Lisse/ Abingdon/ Exton (PA)/ Tokyo.

Hakim, B. (2017). Interpretasi Awal Temuan Gigi Manusia di Situs Bala Metti, Bone dan Situs Leang Jarie, Maros, Sulawesi Selatan. Walennae, 15(1), 19-30.

Landon, D. B. (2005). Zooarchaeology and Historical Archaeology: Progress and Prospect. Journal of Archaeologycal Method and Theory, 12.

Lyman, R. L. (1994). Quantitative Units and Terminology in Zooarchaeology. American Quantitative, 36-71.

Mulvaney, D. J., \& Soejono, R. P. (1970). Archaeology in Sulawesi, Indonesia. Antiquity, 45, 26-33.

Poesponegoro, M. D., Notosusanto, N., Soejono, R. P., \& Leirissa, R. Z. (2009). Sejarah nasional Indonesia Zaman Prasejarah di Indonesia. Jakarta: Balai Pustaka.

Reitz, E. J., \& Wing, E. S. (2008). Zooarchaeology (Second Edi). New York: Cambridge University Press.

Vita. (2002). Pemanfaatan Data Biologi Bagi Kepentingan Arkeologi. Walennae, 5(1), 27-33.

Widianto, H. (2006). Peran dan Pentingnya Fosil Bagi Ilmu pengetahuan. Berkala Arkeologi, 26(1), 77-85. 




DOI: 10.24832/wln.v16i1.314 









DOI: 10.24832/wln.v16i1.314 
Lampiran 4. Peta Lokasi Kawasan Karts dan situs-situs yang tersebar di Bontocani, Kabupaten Bone, Sulawesi Selatan (Sumber: Dokumentasi Balar Sulsel, 2017)

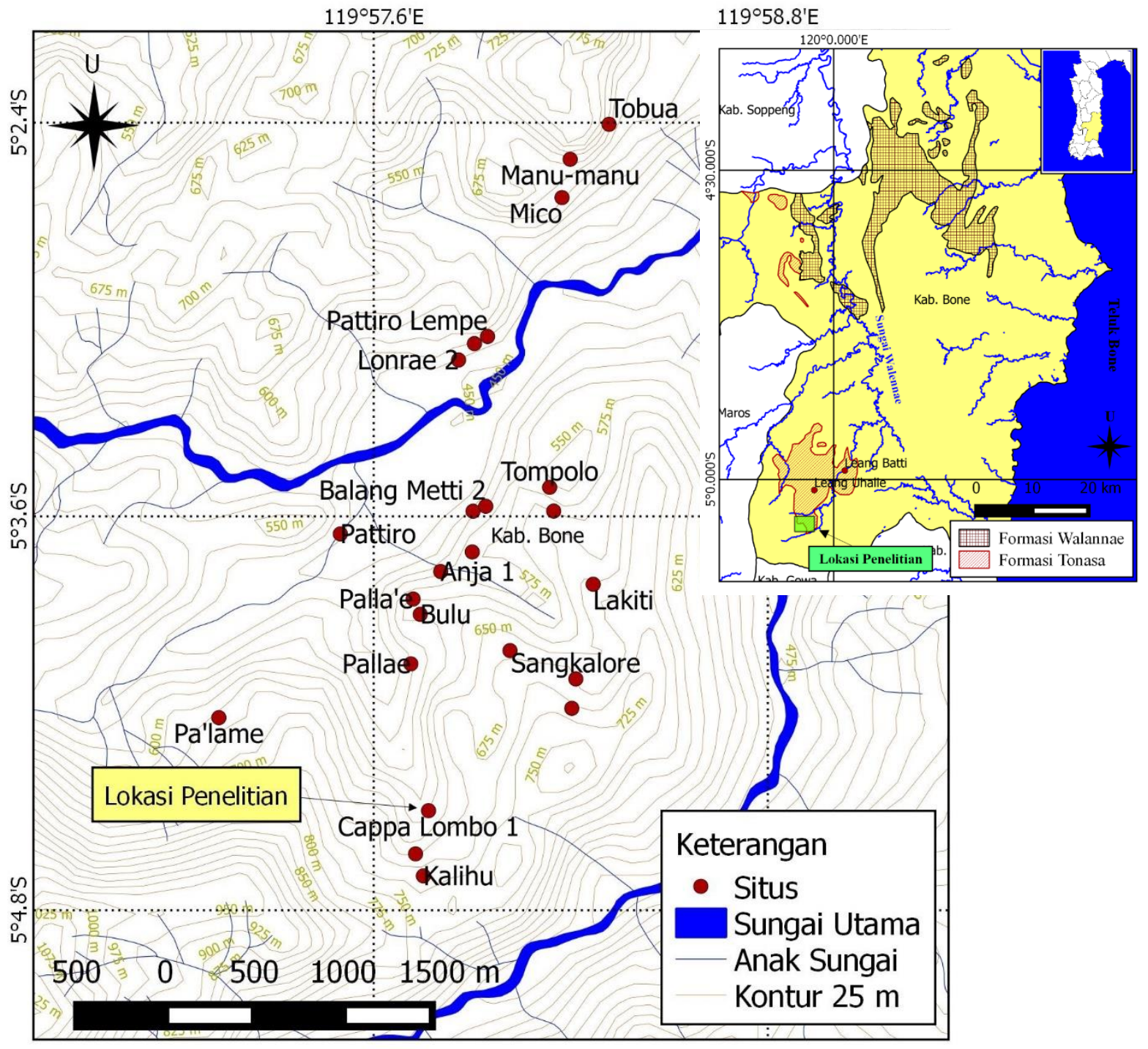

